\title{
EFFECTS OF TEMPERATURE ON SELECTION FOR SCUTELLAR BRISTLES
}

\author{
JOHN GIBSON \\ Department of Genetics, University of Cambridge
}

Received 24.i.70

\section{INTRODUGTION}

Almost all flies from wild-type populations of Drosophila melanogaster have four macrochaetae on the scutellum in an apparently constant pattern. One bristle occurs at each of the two anterior corners of the scutellum and two bristles occur close to the posterior margin of the scutellum. These bristles are referred to as the anterior and posterior bristles, respectively. Occasionally there are interstitial bristles on the dorso-lateral margins of the scutellum between the anterior and posterior sites (Fraser, 1963). Sometimes wild-type flies are found with more than four scutellar bristles and these extra bristles can be at any of the three general regions, although there is considerable variation between populations in the pattern and frequency of extra bristles. In stocks with a variable number of scutellar bristles the number and position of extra bristles can be modified by artificial selection (Payne, 1918; Sismanidis, 1942; Rendel, 1959; Fraser, 1963; Latter, 1964; Finlay, 1965; Druger, 1967; Gibson, 1968) and sometimes by temperature (Child, 1935; Pennycuick and Fraser, 1964; Gibson, 1969). The effects of temperature on scutellar bristle number are particularly interesting because the three regions at which scutellar bristles occur are affected to differing extents by variation of the temperature at which the flies are cultured.

Child $(1935 a, b)$ found that the frequency of extra anterior bristles was highest at $24^{\circ}-25^{\circ} \mathrm{C}$. whilst the frequency of extra posterior bristles was highest at $14^{\circ} \mathrm{C}$. in flies homozygous for the mutant scute. In contrast Rendel and Sheldon (1960) found that the number of anterior bristles increased with decrease in culture temperature in their scute homozygotes but that temperature had little effect in their wild-type Oregon strain except that a high percentage of flies cultured at $30^{\circ} \mathrm{C}$. had extra posterior bristles. A relationship between the pattern of extra bristles and culture temperature was described by Pennycuick and Fraser (1964) for two of their non-scute stocks in which most extra anterior bristles were present at $16^{\circ} \mathrm{C}$. and in one of these stocks the frequency of extra posterior bristles was highest at $30^{\circ} \mathrm{C}$.

Such detectable pattern changes induced by temperature can be used to investigate the interdependence of the genetic systems controlling scutellar bristle number in a way which is not possible with, for example, sternopleural or abdominal bristles in Drosophila. The present paper describes experiments in which the responses to artificial directional selection for extra scutellar bristles in flies cultured at different temperatures are compared, in an attempt to determine whether the genetic factors affecting scutellar bristle number at one temperature are the same as those at other temperatures and whether particular factors affect the same or different chaeta sites when the culture temperature is altered. 


\section{Material AND Methods}

The wild-type population of $D$. melanogaster used in these experiments was derived from three inseminated females taken in Athens in 1964. The non-virgin female progeny were used to produce over one hundred single cultures and from one of these cultures four separate four-pair cultures were set up to initiate the experimental base population at $25^{\circ} \mathrm{C}$. The population was subsequently maintained as four cultures whose progenies were combined before random selection of parents for each generation.

The first laboratory cultures of the Athens stock were assayed by scoring the positions and number of scutellar bristles on 125 flies of each sex. These assays were repeated at two weekly intervals for the next eight generations, when six subcultures each with four pairs of parents were established, two of which were thereafter maintained at each of the temperatures, $29^{\circ} \mathrm{C}$., $25^{\circ} \mathrm{C}$. and $20^{\circ} \mathrm{C}$. One culture at each temperature was maintained without artificial selection and one culture at each temperature was maintained by selecting the four flies of each sex with the highest scutellar bristle numbers as the parents for the next generation. To ensure against the loss of the selected lines, additional cultures were also set up but only used if the main culture failed.

The control and selected lines were assayed at each three weekly generation by scoring 125 flies of each sex of each line. Preliminary experiments had indicated that a three-weekly generation was necessary to ensure that emergence was complete at each temperature before the assays were made. Mating and egg laying in all the lines were carried out at $25^{\circ} \mathrm{C}$. and the cultures were subsequently transferred to the appropriate temperatures before the eggs hatched.

In some experiments the egg-laying period was restricted to four hours and the eggs were collected on yeast-seeded agar disks. $1 \mathrm{ml}$. of a solution of 3 parts ethyl alcohol to 1 part glacial acetic acid was added to the surface of the agar to promote egg laying. The agar disks were placed in $\frac{1}{2}$-pint bottles with standard culture medium and transferred to the relevant environment.

In all assays of control or selected lines the positions of the extra scutellar bristles of each fly were recorded. Fraser's (1963) descriptive classification of anterior and posterior scutellar bristles has been followed, but the term interstitial is used here to describe all bristles that are posterior to the usual anterior sites and anterior to the usual posterior sites. Very few bristles showing spacial displacement in Fraser's sense have been found in this material and the majority of interstitial bristles were readily recognised. The classification becomes particularly subjective, however, when clusters of bristles occur at an anterior site, but the relationships of the two normal anterior bristles to the anterior and dorso-lateral margins of the scutellum have been used as a guide in classifying extra bristles in these clusters. Nevertheless, it is possible that some of the bristles described as interstitial in this material might be classified as anterior on Fraser's criteria.

The mean scutellar bristle numbers of females were consistently higher than those of the corresponding males. As this sex difference did not vary in separate assays the scutellar bristle numbers of females and males have been combined. 


\section{RESULtS}

\section{(i) Effects of temperature on the base population}

During the first eight generations of laboratory culture at $25^{\circ}$ C., $42 \cdot 3$ per cent. of the flies of the Athens stock had extra scutellar bristles and the mean chaeta number of the stock was $4 \cdot 5$. Very few extra posterior bristles were present: 34.7 per cent. of the extra bristles were at anterior sites and 61.0 per cent. were interstitial in position. This distribution of extra bristles is not found in all stocks that have high frequencies of such bristles. For example, in another wild-type stock, Israel, which had been maintained in the laboratory for the same period and has a mean scutellar bristle number of $4 \cdot 5,98 \cdot 8$ per cent. of the extra bristles were anterior in position. These two stocks were both subcultured at $29^{\circ} \mathrm{C}$. and $20^{\circ} \mathrm{C}$., and $125 \mathrm{flies}$ of each sex were assayed at each temperature to investigate the effect of temperature on scutellar bristle number.

Flies of the Athens stock cultured at $20^{\circ} \mathrm{C}$. had a mean scutellar bristle number and a percentage of flies with extra bristles similar to those cultured at $25^{\circ} \mathrm{C}$., but the relative proportions of extra bristles at the three positions were different. At $20^{\circ}$ C. 49 per cent. of the extra bristles were clasisfied as anterior and 51 per cent. as interstitial. At $29^{\circ} \mathrm{C}$. all the extra bristles were in posterior positions. In addition, 10 per cent. of the flies at $29^{\circ} \mathrm{C}$. had less than four bristles and without exception the bristles were missing from anterior sites.

Scutellar bristle number assays of the Israel stock at $20^{\circ} \mathrm{C}$. and $25^{\circ} \mathrm{C}$. showed that these temperatures did not affect the number or position of extra bristles. At $29^{\circ} \mathrm{C}$., however, both the mean bristle number and the proportion of flies with extra bristles were less than at the lower temperatures, but 11 per cent. of the extra bristles were posterior.

Changes in culture temperature therefore had different effects on the two stocks and these data confirm the finding of Pennycuick and Fraser (1964) that the effect of temperature on scutellar bristles cannot be predicted for a particular stock. As the overall effect of temperature was most marked in the Athens stock it was used for subsequent experiments.

\section{(ii) Control lines}

The control lines maintained at each of the three temperatures without artificial selection were assayed each generation for 13 generations for comparison with the directional selection lines.

The line maintained at $25^{\circ} \mathrm{C}$. did not show any overall change in mean scutellar bristle number or in the proportion of flies with extra bristles (fig. 1). The regression coefficient of mean on generations was not significant (table 1). In contrast to this result the control lines maintained at $29^{\circ} \mathrm{C}$. and $20^{\circ} \mathrm{C}$. did change significantly under laboratory natural selection. The regression coefficient of the $29^{\circ} \mathrm{C}$. control line mean on generations was negative and significant whilst that for the $20^{\circ} \mathrm{C}$. line was positive and significant (table 1).

The proportion of flies with extra scutellar bristles increased from 46 per cent. to 73 per cent. at $20^{\circ} \mathrm{C}$. and the mean increased to 5.04 bristles per fly. At $29^{\circ} \mathrm{C}$. both the proportion of flies with extra bristles and the mean bristle number decreased until flies with extra scutellar bristles became very rare, although extra bristles were invariably at posterior sites. 
The relative proportions of extra bristles at the three sites changed in the $20^{\circ} \mathrm{C}$. and $25^{\circ} \mathrm{C}$. control lines (table 2). In both lines the proportions of extra anterior bristles decreased and the proportions of extra interstitial bristles increased over 13 generations. Although the mean scutellar bristle

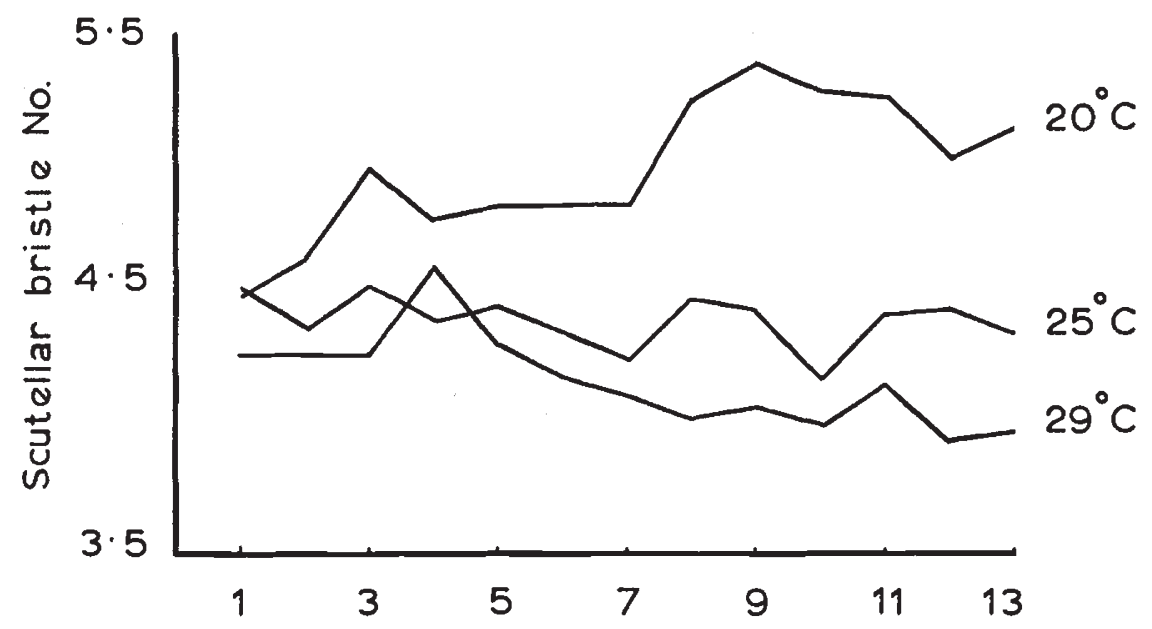

\section{Generations}

Frc. 1.-Mean scutellar bristle numbers of the control lines.

numbers of the two lines had diverged over 13 generations the distributions of the extra bristles had become more similar. The change in bristle pattern in the $20^{\circ} \mathrm{C}$. control line is unlikely to have resulted from misclassification of anterior bristle due to clustering at anterior sites as the $25^{\circ}$ line showed the same pattern change without a correlated change in mean bristle number.

TABLE 1

Analysis of variance of the regression of mean scutellar bristle number over generations for the control lines maintained at $20^{\circ} \mathrm{C}$., $25^{\circ} \mathrm{C}$. and $29^{\circ} \mathrm{C}$.

$\begin{array}{lllrccc}20^{\circ} \mathrm{C} . & \text { S.S. } & \text { dif. } & \mathbf{M}^{\mathbf{2}} & \mathbf{t} & \mathbf{P} \\ & \text { Regression } & 0.4620 & 1 & 0.4620 & 3.3 & 0.01>\mathbf{P}>0.001 \\ & \text { Error } & 0.4662 & 11 & 0.0424 & - & - \\ 29^{\circ} \mathrm{C} . & \text { Total } & 0.9282 & 12 & - & - & - \\ & \text { Regression } & 0.2422 & 1 & 0.2422 & 3.6 & 0.01>\mathbf{P}>0.001 \\ & \text { Error } & 0.2093 & 11 & 0.019 & - & - \\ 25^{\circ} \mathrm{C} . & \text { Total } & 0.4516 & 12 & - & - & - \\ & \text { Regression } & 0.0235 & 1 & 0.0235 & 1.3 & \mathbf{P}>0.2 \\ & \text { Error } & 0.1454 & 11 & 0.0132 & - & - \\ & \text { Total } & 0.1689 & 12 & - & - & -\end{array}$

After 15 generations the $25^{\circ} \mathrm{C}$. control line was subcultured for one generation at $20^{\circ} \mathrm{C}$. and $29^{\circ} \mathrm{C}$. Scutellar bristle number assays of the subcultures (table 3 ) showed that at $20^{\circ} \mathrm{C}$. both the proportion of flies with extra bristles and the mean bristle number were higher than when the line was first subcultured at $20^{\circ} \mathrm{C}$. at the start of the experiment. The effect of culturing the line at $29^{\circ} \mathrm{C}$., however, had not changed. 
The changes in scutellar bristle number mean in the control lines at the three temperatures are in the same direction as those observed for sternopleural bristles in stocks maintained at $20^{\circ} \mathrm{C}$., $25^{\circ} \mathrm{C}$. and $29^{\circ} \mathrm{C}$.

TABle 2

The percentages of extra bristles at the three sites in the $20^{\circ} \mathrm{C}$. and $25^{\circ} \mathrm{C}$. control lines at generations 1 and 13

C 20

$\begin{array}{cccc} & \text { P } & \text { A } & \text { I } \\ \mathrm{S}_{1} & - & 59.5 & 40.5 \\ \mathrm{~S}_{13} & 0.4 & 25.4 & 74.2\end{array}$

C 25

$\begin{array}{cccc} & \text { P } & \text { A } & \text { I } \\ \mathbf{S}_{1} & 2 \cdot 3 & 40.2 & 57 \cdot 5 \\ \mathbf{S}_{18} & 5 \cdot 0 & 26.9 & 68 \cdot 1\end{array}$

(Beardmore in Thoday, 1958). In the present experiments measures of viability were not made at the three temperatures so that it is not possible to say whether or not scutellar bristle number has some adaptive significance such as was postulated for sternopleural bristle number.

TABle 3

Effect of temperature on the $25^{\circ} \mathrm{C}$. control line after 15 generations

$\begin{array}{lccr}25^{\circ} \mathrm{C} . & \begin{array}{c}25^{\circ} \mathrm{C} . \text { line } \\ \text { cultured } \\ \text { at } 20^{\circ} \mathrm{C} .\end{array} & \begin{array}{r}25^{\circ} \mathrm{C} . \\ \text { cultured } \\ \text { at } 29^{\circ} \mathrm{C} .\end{array} \\ \begin{array}{l}\text { Percentage of } \\ \text { lines with }\end{array} & & & \\ \quad \text { extra bristles } & 36.8 & 74.8 & 19.5 \\ \text { Mean } & 4.5 & 5.1 & 4.2\end{array}$

\section{(iii) The selected lines}

The changes in mean scutellar bristle number in the three selected lines (fig. 2) were very different from one another. The $20^{\circ} \mathrm{C}$. selected line showed the most rapid response and reached a mean of $7 \cdot 1$ bristles per fly after only seven generations. Thereafter, very little progress under selection was made, the highest mean attained was 7.5 after 25 generations of selection. After generation 30 the line was maintained in mass culture without artificial selection and when next assayed ten generations later the mean had fallen to $6 \cdot 7$, a value maintained in subsequent assays.

Neither the $29^{\circ} \mathrm{C}$. nor the $25^{\circ} \mathrm{C}$. selected lines reached as high a mean scutellar bristle number as the $20^{\circ} \mathrm{C}$. line. The $25^{\circ} \mathrm{C}$. line responded faster than the $29^{\circ} \mathrm{C}$. line and had a mean of 6.5 at generation 27 , after which it fluctuated around 6.25 for the next 11 generations.

The $29^{\circ} \mathrm{C}$. selected line responded very slowly to directional selection. The line was difficult to maintain and on a number of occasions complete assays were not possible. After generation 24 the cultures were more successful and the line mean increased from 4.8 to 6.2 in nine generations. For the next six generations the cultures again deteriorated and the mean fell sharply to 4.4 bristles per fly.

The change in proportions of bristles at the three sites in the $20^{\circ} \mathrm{C}$. selected line did not mirror the changes which occurred in the $20^{\circ} \mathrm{C}$. control line. In the selected line the proportion of extra bristles at anterior sites increased from 49 per cent. to 67 per cent. in 15 generations and the 
proportion of extra interstitial bristles decreased. Less than 3 per cent. of the extra bristles in this line were at posterior sites (fig. 3).

The increase in mean scutellar bristle number over the first four generations in the $25^{\circ} \mathrm{C}$. line was not accompanied by changes in bristle pattern and the proportion of extra bristles at each of the three sites was similar to the $25^{\circ} \mathrm{C}$. controls, 63 per cent. of the extra bristles were interstitial and 34 per cent. were anterior in position (fig. 3). Thereafter the proportion of extra anterior bristles increased and at generation 28 the relative proportions of extra bristles at the three sites were similar in the $25^{\circ} \mathrm{C}$. and the $20^{\circ}$ C. selected lines (fig. 3).

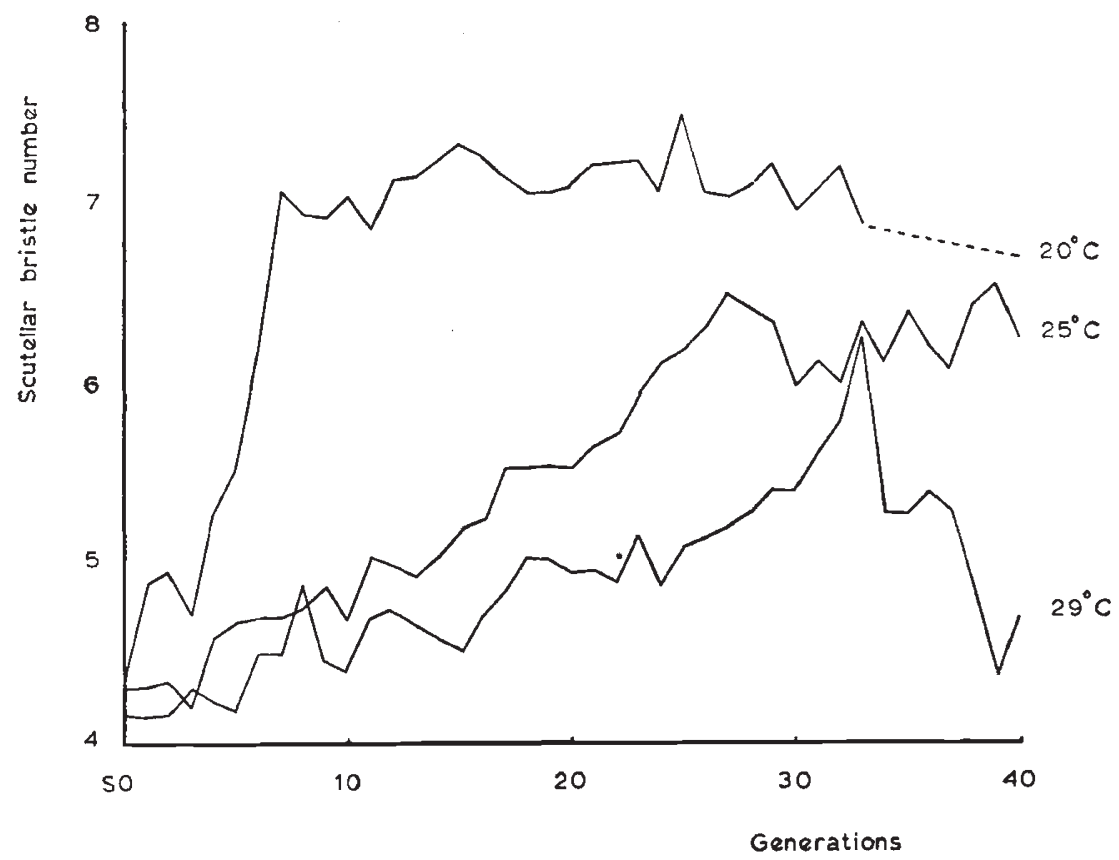

Fig. 2.-Mean scutellar bristle numbers of the selected lines.

All of the extra bristles in the $29^{\circ} \mathrm{C}$. line were posterior in the first generation of selection but this proportion was not maintained as the mean scutellar bristle number increased for at generation 14,60 per cent. of the extra bristles were posterior and 35 per cent. interstitial (fig. 3).

At generation 14 subcultures of the three selected lines were assayed at each of the three temperatures. The results (table 4 ) show that each of the three lines has a higher mean scutellar bristle number at $20^{\circ} \mathrm{C}$. than at $29^{\circ} \mathrm{C}$. and in each line the proportion of flies with extra bristles is also inversely related to the culture temperature. Included in table 5 are the proportion of extra bristles at the three sites in each line and these data show that the proportion of extra posterior bristles increases and the proportion of extra anterior bristles decreases with a rise in culture temperature. The proportion of extra interstitial bristles in each line is highest at $25^{\circ} \mathrm{C}$.

Prior selection in an adverse environment can sometimes increase the response to selection for a quantitative character in a more favourable environment (Falconer, 1960). Clearly, $29^{\circ} \mathrm{C}$. is less suitable than $20^{\circ} \mathrm{C}$. 

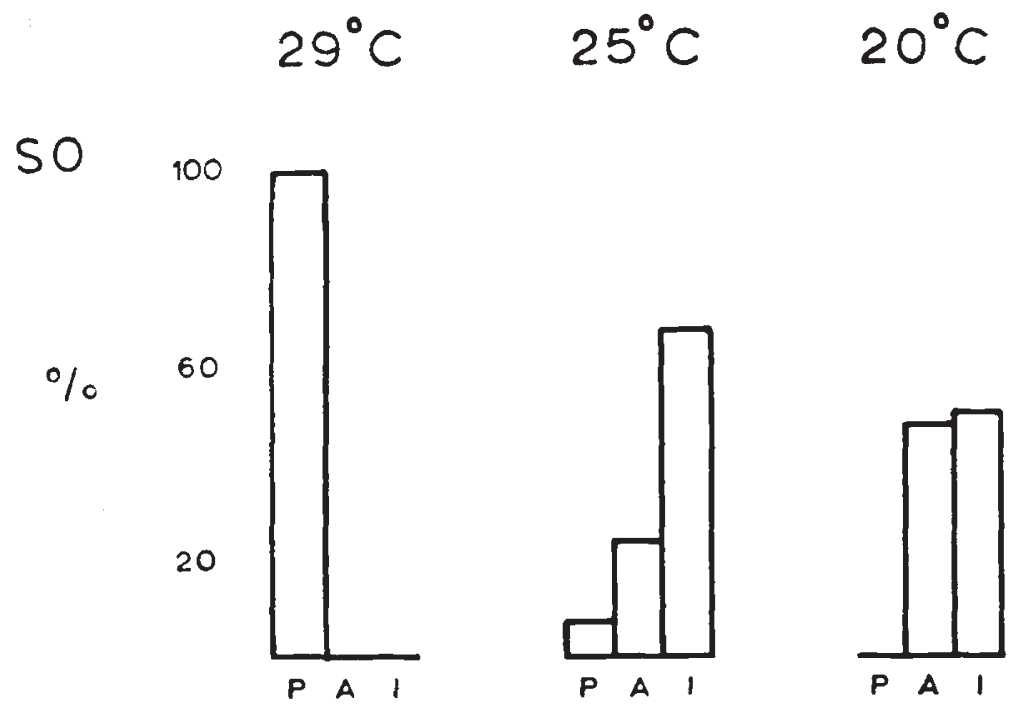

$514 \quad 100$

$\%$
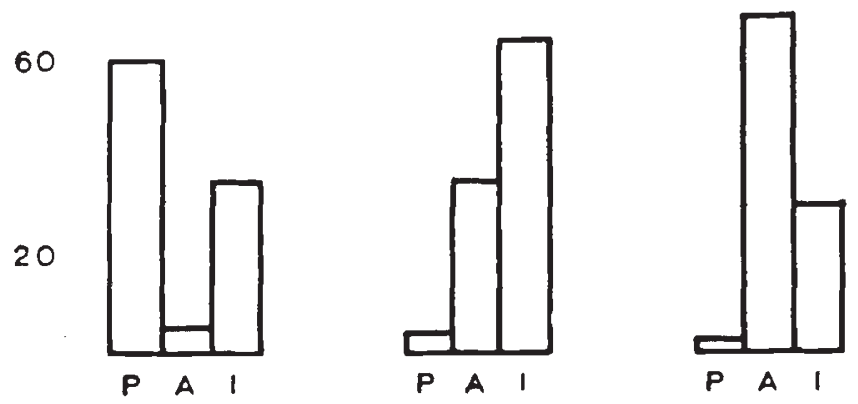

$\$ 28 \quad 100$
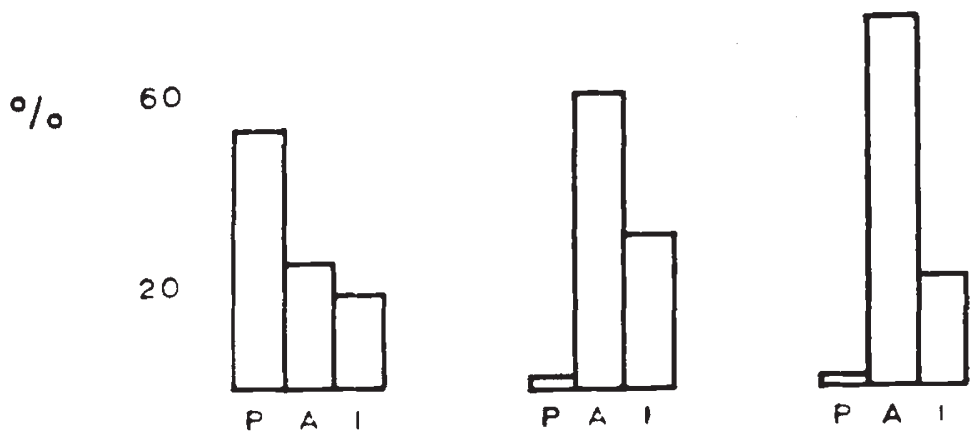

Fig. 3.--Proportion of extra bristles at the three sites in the selected lines. 2 Q 
for selection for high scutellar bristle number in the present material. By generation 20 the $29^{\circ} \mathrm{C}$. and $20^{\circ} \mathrm{C}$. lines appeared to have plateaued and so could be used to see whether any genetic variance remained in these two lines which could be exploited in different environments. In fact, the mean scutellar bristle number of the $29^{\circ} \mathrm{C}$. line increased further after generation 20 but the assumption that the $20^{\circ} \mathrm{C}$. line had reached a plateau at generation 20 seemed to be valid.

Subcultures of the $29^{\circ} \mathrm{C}$. selected line were set up at $20^{\circ} \mathrm{C}$. and selected for 22 generations for high scutellar bristle number. The converse test was applied to the $20^{\circ} \mathrm{C}$. selected line which was subcultured and subsequently selected at $29^{\circ} \mathrm{C}$.

\section{TABLE 4}

Scutellar bristle number assays of the $29^{\circ} \mathrm{C} ., 25^{\circ} \mathrm{C}$. and $20^{\circ} \mathrm{C}$. selected lines cultured for one generation at the three temperatures

\begin{tabular}{|c|c|c|c|c|c|c|}
\hline \multirow[b]{2}{*}{$\begin{array}{c}\text { Culture } \\
\text { temperature }\end{array}$} & \multirow[b]{2}{*}{$\begin{array}{l}\text { Selected } \\
\text { line }\end{array}$} & \multirow{2}{*}{$\begin{array}{l}\text { Mean } \\
\text { bristle } \\
\text { number }\end{array}$} & \multirow{2}{*}{$\begin{array}{c}\text { Percentage of } \\
\text { flies } \\
\text { with extra } \\
\text { bristles }\end{array}$} & \multicolumn{3}{|c|}{$\begin{array}{l}\text { Percentage of extra } \\
\text { bristles at the three sites }\end{array}$} \\
\hline & & & & $P$ & A & $\vec{I}$ \\
\hline $29^{\circ} \mathrm{C}$. & $\begin{array}{l}29^{\circ} \mathrm{C} \text {. line } \\
25^{\circ} \mathrm{C} \text {. line } \\
20^{\circ} \mathrm{C} \text {. line }\end{array}$ & $\begin{array}{l}4 \cdot 5 \\
4 \cdot 4 \\
5 \cdot 4\end{array}$ & $\begin{array}{l}36 \cdot 0 \\
30 \cdot 0 \\
76 \cdot 4\end{array}$ & $\begin{array}{l}59 \cdot 6 \\
52 \cdot 2 \\
64 \cdot 1\end{array}$ & $\begin{array}{l}5 \cdot 8 \\
6 \cdot 6 \\
9 \cdot 1\end{array}$ & $\begin{array}{l}34 \cdot 6 \\
41 \cdot 2 \\
26 \cdot 8\end{array}$ \\
\hline $25^{\circ} \mathrm{C}$. & $\begin{array}{l}29^{\circ} \mathrm{C} \text {. line } \\
25^{\circ} \mathrm{C} \text {. line } \\
20^{\circ} \mathrm{C} \text {. line }\end{array}$ & $\begin{array}{l}5 \cdot 3 \\
5 \cdot 2 \\
6 \cdot 7\end{array}$ & $\begin{array}{l}75 \cdot 0 \\
70 \cdot 8 \\
96 \cdot 4\end{array}$ & $\begin{array}{l}4 \cdot 8 \\
2 \cdot 8 \\
3 \cdot 9\end{array}$ & $\begin{array}{l}28 \cdot 6 \\
34 \cdot 5 \\
53 \cdot 4\end{array}$ & $\begin{array}{l}66 \cdot 4 \\
62 \cdot 7 \\
43 \cdot 7\end{array}$ \\
\hline $20^{\circ} \mathrm{C}$. & $\begin{array}{l}29^{\circ} \mathrm{C} \text {. line } \\
25^{\circ} \mathrm{C} \text {. line } \\
20^{\circ} \mathrm{C} \text {. line }\end{array}$ & $\begin{array}{l}5 \cdot 4 \\
5 \cdot 5 \\
6 \cdot 8\end{array}$ & $\begin{array}{l}79 \cdot 4 \\
87 \cdot 2 \\
95 \cdot 6\end{array}$ & $\frac{7 \cdot 0}{2 \cdot 6}$ & $\begin{array}{l}43 \cdot 8 \\
58 \cdot 2 \\
66 \cdot 6\end{array}$ & $\begin{array}{l}49 \cdot 2 \\
41 \cdot 8 \\
30 \cdot 8\end{array}$ \\
\hline
\end{tabular}

The results (fig. 4) show that each of these lines responded to selection in the new environments but that the responses were more gradual and the mean scutellar bristle numbers reached were lower than in the lines originally selected in these environments. The $29^{\circ} \mathrm{C}$. line selected at $20^{\circ} \mathrm{C}$. showed the greatest response and had a mean scutellar bristle number of 7 after 15 generations of selection. Thereafter the mean was maintained at a similar level to that maintained for the original $20^{\circ} \mathrm{C}$. selected line. The distributions of extra bristles in these two lines were not different (table 5).

The $20^{\circ} \mathrm{C}$. line selected at $29^{\circ} \mathrm{C}$. did not attain as high a mean as the original $29^{\circ} \mathrm{C}$. line, but it proved possible to maintain at a mean of 5.5 bristles whereas the original line was difficult to maintain at 4.5 bristles per fly. The number of extra bristles at the three sites in these two lines were significantly different $\left(\chi_{2}^{2}=25 \cdot 9\right)$. The $20^{\circ} \mathrm{C}$. line selected at $29^{\circ} \mathrm{C}$. had more extra posterior scutellar bristles than the original $29^{\circ} \mathrm{C}$. line and fewer extra anterior bristles (table 5).

These data show that prior selection in an adverse environment need not necessarily lead to greater response in a more favourable environment. They also indicate that prior selection at $29^{\circ} \mathrm{C}$. does not lead to an increase in the proportion of extra posterior bristles when the line subsequently reaches a higher mean at a lower temperature.

Nevertheless, it is clear that the original $20^{\circ} \mathrm{C}$. selected line contained genetic variance for scutellar bristle number which could not be utilised 
at $20^{\circ} \mathrm{C}$. but could be utilised at $29^{\circ} \mathrm{C}$. It is not possible to make the same assumptions about the selected $29^{\circ} \mathrm{C}$. line because this line continued to respond to selection at $29^{\circ}$ G. after the sub-line had been taken out at generation 21 .

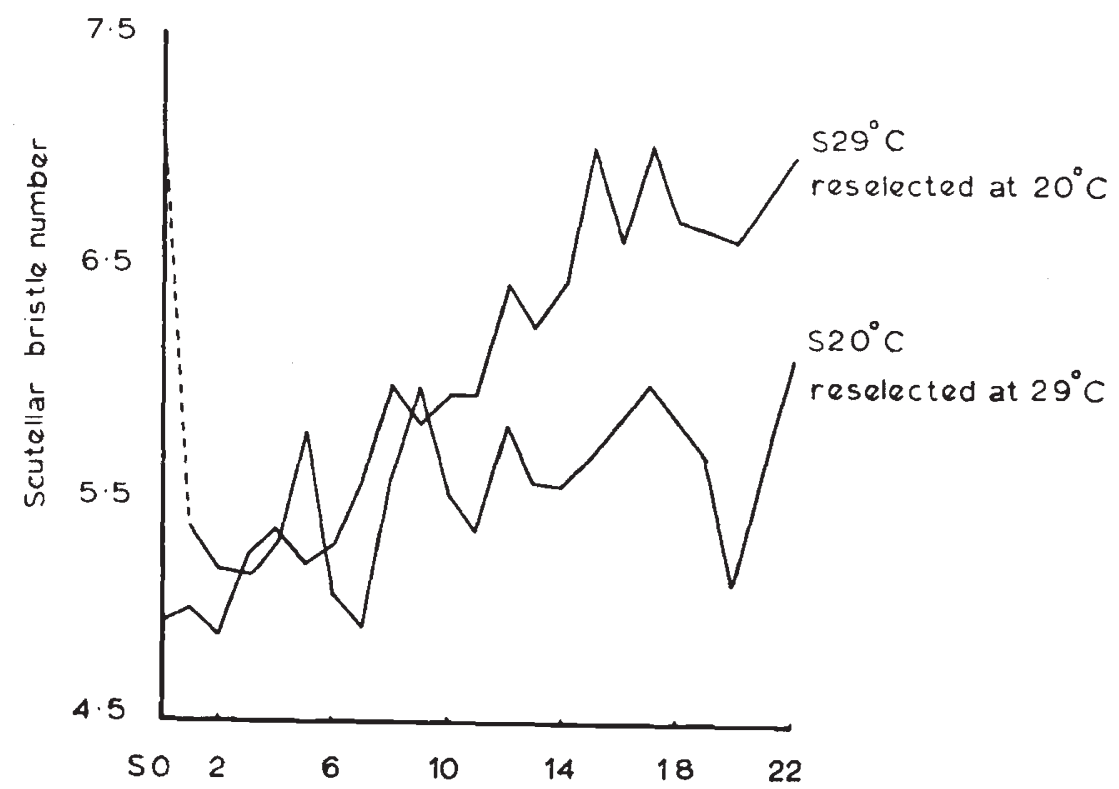

(S21)

Generations

Fig. 4.-Mean scutellar bristle numbers of the $20^{\circ}$ C. selected line reselected at $29^{\circ} \mathrm{C}$. and of the $29^{\circ} \mathrm{C}$. selected line reselected at $20^{\circ} \mathrm{C}$.

The exploitation of genetic variance in these sub-lines by selection in new environments might have altered their performance in the original environments. Both the $20^{\circ} \mathrm{C}$. line selected at $29^{\circ} \mathrm{C}$. and the $29^{\circ} \mathrm{C}$. line

TABLE 5

Comparison of the selected lines assayed at the final generation of selection

\begin{tabular}{|c|c|c|c|c|c|}
\hline & \multirow{2}{*}{$\begin{array}{c}\text { Mean } \\
\text { bristle } \\
\text { number }\end{array}$} & \multirow{2}{*}{$\begin{array}{l}\text { Percentage of } \\
\text { flies with } \\
\text { extra bristles }\end{array}$} & \multicolumn{3}{|c|}{$\begin{array}{l}\text { Percentage of extra bristles } \\
\text { of the three sites }\end{array}$} \\
\hline & & & $\mathbf{P}$ & A & I \\
\hline $\begin{array}{l}20^{\circ} \mathrm{C} \text {. line selected } \\
\text { at } 29^{\circ} \mathrm{C} \text {. }\end{array}$ & $6 \cdot 1$ & 94.4 & 57.9 & 18.9 & 23.2 \\
\hline $\begin{array}{l}29^{\circ} \mathrm{C} \text {. line } \\
29^{\circ} \mathrm{C} \text {. line selected }\end{array}$ & $4 \cdot 7$ & 42.2 & 38.2 & $43 \cdot 6$ & 18.2 \\
\hline $\begin{array}{l}\text { at } 20^{\circ} \mathrm{C} \text {. } \\
20^{\circ} \mathrm{C} \text {. line }\end{array}$ & $\begin{array}{l}6 \cdot 9 \\
6 \cdot 9\end{array}$ & $\begin{array}{l}98 \cdot 0 \\
98 \cdot 6\end{array}$ & $\begin{array}{l}2 \cdot 3 \\
0 \cdot 3\end{array}$ & $\begin{array}{l}76 \cdot 5 \\
72 \cdot 5\end{array}$ & $\begin{array}{l}21 \cdot 2 \\
27 \cdot 2\end{array}$ \\
\hline
\end{tabular}

selected at $20^{\circ} \mathrm{C}$. were subcultured at their original temperatures after 21 generations of selection. The results (table 6) show that neither the mean scutellar bristle number nor the proportions of extra bristles at the three sites had been altered in the $20^{\circ} \mathrm{C}$. lines. Reselection of the $29^{\circ} \mathrm{C}$. line at 
$20^{\circ} \mathrm{C}$. however, had changed its performance at $29^{\circ} \mathrm{C}$. The mean scutellar bristle number was increased and the proportion of extra bristles at posterior sites was higher than in the original line.

\section{(iv) Whole chromosome assays}

Attempts were made to investigate the effect on scutellar bristle number of whole chromosomes extracted from the control and selected lines to determine whether or not the same genetic material was involved at each temperature.

\section{TABLE 6}

Scutellar bristle number assays of the $29^{\circ} \mathrm{C}$. line reselected at $20^{\circ} \mathrm{C}$. and the $20^{\circ} \mathrm{C}$. line reselected at $29^{\circ} \mathrm{C}$. when these two lines were cultured at $29^{\circ} \mathrm{C}$. and $20^{\circ} \mathrm{C}$. respectively

\begin{tabular}{|c|c|c|c|c|c|c|}
\hline \multirow[b]{2}{*}{$\begin{array}{l}\text { Culture } \\
\text { temperature }\end{array}$} & \multirow[b]{2}{*}{ Line } & \multirow{2}{*}{$\begin{array}{l}\text { Mean } \\
\text { bristle } \\
\text { number }\end{array}$} & \multirow{2}{*}{$\begin{array}{l}\text { Percentage of } \\
\text { flies with } \\
\text { extra bristles }\end{array}$} & \multicolumn{3}{|c|}{$\begin{array}{l}\text { Percentage of extra bristles } \\
\text { at the three sites }\end{array}$} \\
\hline & & & & P & $\overbrace{A}^{A}$ & $\mathrm{I}$ \\
\hline At $20^{\circ} \mathrm{C}$. & $\begin{array}{l}20^{\circ} \mathrm{C} \text {. line } \\
\text { selected } \\
\text { line }\end{array}$ & $6 \cdot 7$ & $97 \cdot 3$ & - & 80.7 & $19 \cdot 3$ \\
\hline & $\begin{array}{l}20^{\circ} \mathrm{C} \text {. line } \\
\text { reselected } \\
\text { at } 29^{\circ} \mathrm{C} \text {. }\end{array}$ & $6 \cdot 6$ & $97 \cdot 0$ & 0.7 & $84 \cdot 7$ & $14 \cdot 6$ \\
\hline At $29^{\circ} \mathrm{C}$. & $29^{\circ} \mathrm{C}$. line & $4 \cdot 7$ & $42 \cdot 4$ & $38 \cdot 2$ & $43 \cdot 6$ & $18 \cdot 2$ \\
\hline & $\begin{array}{l}29^{\circ} \mathrm{C} \text {. line } \\
\text { reselected } \\
\text { at } 20^{\circ} \mathrm{C} \text {. }\end{array}$ & $5 \cdot 0$ & $55 \cdot 2$ & 69.9 & $24 \cdot 4$ & $5 \cdot 7$ \\
\hline
\end{tabular}

Reciprocal crosses between the Athens base stock and a $y$ bw st marker stock were made at each temperature. These progenies contained very few flies with extra bristles and test cross-progenies were not undertaken. At $29^{\circ}$ C., 5.3 per cent. of the $F_{1}$ progeny had less than four scutellar bristles and all the missing bristles were from anterior sites. Unfortunately, attempts to breed from flies with less than four bristles were unsuccessful.

In a preliminary experiment to assay homozygous effects of autosomes, males from the Athens base stock were crossed to $P m M e ́$ females and the resulting $P m M \dot{\delta}$ progeny were intermated and cultured at $20^{\circ} \mathrm{C}$. Progeny of both sexes from each of the four resulting genotypes were assayed for scutellar bristle number. The results (table 7 ) show that at $20^{\circ} \mathrm{C}$. flies homozygous for Athens second and third chromosomes had a similar mean scutellar bristle number to the Athens stock cultured at $20^{\circ} \mathrm{C}$. However, flies heterozygous for $\mathrm{Pm}$ and Athens second chromsomoes and homozygous for Athens third chromosomes had a higher mean scutellar bristle number than the Athens stock cultured at $20^{\circ} \mathrm{G}$. Cultures at $20^{\circ} \mathrm{G}$. of a $P m M e ́$ stock with an Oregon background did not produce any flies with more than four scutellar bristles. Thus Athens second chromosomes when homozygous inhibited the effect of the Athens third chromosomes when the latter were homozygous. Such negative interactions (for which Fraser et al. (1965) used the term "compensative interaction ") might be expected to occur and play an important role in stabilising scutellar bristle number by buffering against temporary changes in temperature during development (Gibson, 
1969). If the Athens stock is not homogeneous for these interacting chromosomes, a higher mean scutellar bristle number could readily be attained. It is interesting that the mean scutellar bristle number did increase in the Athens control line maintained at $20^{\circ} \mathrm{C}$. to a level approaching that which would be predicted if the negative interaction were removed. Also the $25^{\circ} \mathrm{C}$. control line after 15 generations was more responsive to lower temperatures suggesting that the negative interaction had been lost at $25^{\circ} \mathrm{C}$.

TABLE 7

Chromosome assays of the Athens base stock relative to Pm Mé

$\begin{array}{cccc}\text { Genotypes } & \begin{array}{c}\text { Mean bristle } \\ \text { number }\end{array} & n & \begin{array}{c}\text { Percentage of } \\ \text { flies with } \\ \text { extra bristles }\end{array} \\ + \pm+ & 4.5 & 133 & 38.3 \\ ++ & & & \\ P_{m} M \varepsilon & 4.4 & 114 & 52.2 \\ \overline{+}+ & & & \\ P_{m}+ & 5.6 & 112 & 68.9 \\ +\overline{+} & & & \\ +M \varepsilon & 4.3 & 193 & 23.2 \\ +\overline{+} & & & \end{array}$

\begin{tabular}{|c|c|c|c|}
\hline \multicolumn{4}{|c|}{ Analysis of variance } \\
\hline Source & d.f. & $\begin{array}{l}\text { Mean } \\
\text { square }\end{array}$ & $\mathbf{P}$ \\
\hline $\begin{array}{l}\text { Chromosome II } \\
\text { Chromosome III } \\
\text { II X III }\end{array}$ & $\begin{array}{l}1 \\
1 \\
1\end{array}$ & $\begin{array}{r}100 \cdot 74 \\
62 \cdot 11 \\
15 \cdot 31\end{array}$ & $\begin{array}{l}<0.001 \\
<0.001 \\
<0.001\end{array}$ \\
\hline $\begin{array}{l}\text { Sex } \\
\text { Sex } \times \text { II } \\
\text { Sex } \times \text { III } \\
\text { Sex II } \times \text { III } \\
\text { Individuals (error) }\end{array}$ & $\begin{array}{r}1 \\
1 \\
1 \\
1 \\
544\end{array}$ & $\begin{array}{r}13 \cdot 46 \\
2.04 \\
6 \cdot 29 \\
2 \cdot 17 \\
0.69\end{array}$ & $\begin{aligned} & <0.001 \\
& >0.05 \\
0.01 & <,>0.001 \\
> & 0.05 \\
& -\end{aligned}$ \\
\hline Total & 551 & - & - \\
\hline
\end{tabular}

A standard breeding programme utilising marked inversions on each of the three major chromosomes was later used to isolate for assay homozygotes of Athens $25^{\circ} \mathrm{C}$. control line and $20^{\circ} \mathrm{C}$. selected line chromosomes on an Oregon background. As $y$ bw st assays had shown that none of the $\mathrm{X}$ chromosomes derived from the control or the selected lines had any appreciable individual effect on scutellar bristle number these will be ignored, although it is possible that $\mathrm{X}$ chromosomes from the selected lines did contribute slightly to the total effect by interchromosomal interactions In a few assays where such $\mathrm{X}$ chromosome interactions might have been detected, none was observed.

Inviability interactions between some of the balancer chromosomes, and possibly the extracted chromosomes, prevented complete analyses being $2 Q^{2}$ 
made. Unfortunately such interactions make it probable that non-random samples of extracted chromosomes were eventually assayed.

TABLE 8

Scutellar bristle number assays of fies homozygous for third chromosomes extracted from the $25^{\circ} \mathrm{C}$. control line on an Oregon background

\begin{tabular}{|c|c|c|c|c|c|}
\hline \multirow{2}{*}{$\begin{array}{l}\text { Culture } \\
\text { temperature }\end{array}$} & \multirow{2}{*}{$\begin{array}{l}\text { Mean } \\
\text { bristle } \\
\text { number }\end{array}$} & \multirow{2}{*}{$\begin{array}{l}\text { Percentage of } \\
\text { flies with } \\
\text { extra bristles }\end{array}$} & \multicolumn{3}{|c|}{$\begin{array}{l}\text { Percentage of extra bristles } \\
\text { at the three sites }\end{array}$} \\
\hline & & & $P$ & A & $\vec{I}$ \\
\hline $\begin{array}{l}25^{\circ} \mathrm{C} \text {. } \\
29^{\circ} \mathrm{C} \text {. } \\
20^{\circ} \mathrm{C} \text {. }\end{array}$ & $\begin{array}{l}4 \cdot 6 \\
4 \cdot 4 \\
4 \cdot 4\end{array}$ & $\begin{array}{l}38 \cdot 2 \\
28 \cdot 8 \\
32 \cdot 8\end{array}$ & $\begin{array}{r}0.7 \\
90.6 \\
\end{array}$ & $\begin{array}{r}37 \cdot 1 \\
5 \cdot 7 \\
65 \cdot 4\end{array}$ & $\begin{array}{r}62 \cdot 2 \\
3.7 \\
34 \cdot 6\end{array}$ \\
\hline
\end{tabular}

Second chromosomes extracted from both the $25^{\circ} \mathrm{C}$. and $20^{\circ} \mathrm{C}$. control lines had no individual effects on scutellar bristle number. The extracted second chromosomes from the $25^{\circ} \mathrm{C}$. control line were assayed on an Oregon

\section{Table 9}

Mean scutellar bristle numbers of fies containing combinations of second and third chromosomes extracted from the $20^{\circ} \mathrm{C}$. selected line on an Oregon background

\begin{tabular}{|c|c|c|c|c|}
\hline \multirow{2}{*}{ S 20} & & \multicolumn{3}{|c|}{ Number of third chromosomes } \\
\hline & & 0 & 1 & 2 \\
\hline $\begin{array}{l}\text { Number of } \\
\text { second } \\
\text { chromosomes }\end{array}$ & $\begin{array}{l}0 \\
1 \\
2\end{array}$ & $\begin{array}{l}4 \cdot 0 \\
4 \cdot 0 \\
4 \cdot 4\end{array}$ & $\begin{array}{l}4 \cdot 1 \\
4 \cdot 4 \\
5 \cdot 1\end{array}$ & $\begin{array}{l}4 \cdot 6 \\
4 \cdot 7 \\
7 \cdot 3\end{array}$ \\
\hline
\end{tabular}

\begin{tabular}{|c|c|c|c|}
\hline \multicolumn{4}{|c|}{ Analysis of variance } \\
\hline Source & d.f. & $\begin{array}{l}\text { Mean } \\
\text { squares }\end{array}$ & Probability \\
\hline $\begin{array}{l}\text { Chromosome II } \begin{array}{l}\text { additive } \\
\text { dominance }\end{array} \\
\text { Chromosome III additive } \\
\text { dominance }\end{array}$ & $\begin{array}{l}1 \\
1 \\
1 \\
1\end{array}$ & $\begin{array}{r}48 \cdot 4 \\
171 \cdot 4 \\
224 \cdot 8 \\
129 \cdot 9\end{array}$ & $\begin{array}{l}<0.001 \\
<0.001 \\
<0.001 \\
<0.001\end{array}$ \\
\hline Additive II $\times$ additive III & 1 & $47 \cdot 1$ & $<0.001$ \\
\hline Additive II $\times$ dominance III & 1 & 1.3 & \\
\hline Dominance II $x$ additive III & 1 & 49.9 & $<0.001$ \\
\hline Dominance II $\times$ dominance III & 1 & $69 \cdot 3$ & $<0.001$ \\
\hline Sex & 1 & $85 \cdot 1$ & $<0.001$ \\
\hline Sex $\times$ II & 2 & $7 \cdot 2$ & $\begin{array}{l}<0.01 \\
>0.001\end{array}$ \\
\hline Sex $\times$ III & 2 & $6 \cdot 1$ & $\begin{array}{l}<0.01 \\
>0.001\end{array}$ \\
\hline $\operatorname{Sex} \times I I \times I I I$ & 4 & $2 \cdot 6$ & $>0.05$ \\
\hline Individuals (error) & 2473 & $1 \cdot 1$ & \\
\hline
\end{tabular}

background at each of the three temperatures and in each case the effect on scutellar bristles was very slight. The individual effects of homozygous third chromosomes extracted from the $25^{\circ} \mathrm{C}$. control lines (table 8) were sufficient to explain the mean scutellar bristle number of the line. However, third chromosomes extracted from the $20^{\circ} \mathrm{C}$. control line after 13 generations at 
$20^{\circ} \mathrm{C}$. had no individual effects on scutellar bristle number when homozygous. The mean scutellar bristle number of the $20^{\circ} \mathrm{C}$. control line was maintained by interactions between the second and third chromosomes. Thus the negative interaction between the second and third chromosomes present in the Athens stock when it was originally cultured at $20^{\circ} \mathrm{C}$. had been replaced during natural selection at $20^{\circ} \mathrm{C}$. by a positive interaction between these chromosomes increasing scutellar bristle number.

The proportions of extra bristles at the three sites produced by third chromosomes extracted from the $25^{\circ} \mathrm{C}$. control line varied with the assay culture temperature. At $29^{\circ}$ G., 90 per cent. of the extra bristles were at posterior sites whereas at $25^{\circ} \mathrm{C}$. and $20^{\circ} \mathrm{C}$. very few extra posterior bristles occurred. Thus the same chromosome can give rise to different scutellar bristle number phenotypes at different temperatures.

\section{TABLe 10}

Scutellar bristle number assays of fies containing combinations of chromosomes extracted from the $20^{\circ} \mathrm{C}$. selected line assayed at $20^{\circ} \mathrm{C} ., 25^{\circ} \mathrm{C}$. and $29^{\circ} \mathrm{C}$.

\begin{tabular}{|c|c|c|c|c|c|c|}
\hline & & $\begin{array}{l}\text { Mean } \\
\text { bristle }\end{array}$ & $\begin{array}{c}\text { Percentage } \\
\text { of flies } \\
\text { with extra }\end{array}$ & $\begin{array}{l}\text { Perc } \\
\text { bris }\end{array}$ & $\begin{array}{l}\text { ntage o } \\
\text { s at the } \\
\text { sites }\end{array}$ & $\begin{array}{l}\text { xtra } \\
\text { hree }\end{array}$ \\
\hline & temperature & number & bristles & $\mathbf{P}$ & A & I \\
\hline $\begin{array}{l}\text { Flies homozygous } \\
\text { or hemizygous for } \\
\text { an extracted X } \\
\text { chromosome }\end{array}$ & $\begin{array}{l}20^{\circ} \mathrm{C} \text {. } \\
25^{\circ} \mathrm{C} . \\
29^{\circ} \mathrm{C} .\end{array}$ & $\begin{array}{l}4 \cdot 0 \\
4 \cdot 0 \\
4 \cdot 0\end{array}$ & $\begin{array}{l}0.8 \\
0.4 \\
-\end{array}$ & - & $\begin{array}{r}50 \\
100 \\
-\end{array}$ & $\frac{50}{-}$ \\
\hline $\begin{array}{l}\text { Flies homozygous } \\
\text { for an extracted } \\
\text { second chromosome }\end{array}$ & $\begin{array}{l}20^{\circ} \mathrm{C} \text {. } \\
25^{\circ} \mathrm{C} . \\
29^{\circ} \mathrm{C} .\end{array}$ & $\begin{array}{l}4 \cdot 4 \\
4 \cdot 3 \\
4 \cdot 4\end{array}$ & $\begin{array}{l}29 \cdot 4 \\
26 \cdot 4 \\
26 \cdot 8\end{array}$ & $\begin{array}{r}\overline{2 \cdot 2} \\
90 \cdot 6\end{array}$ & $\begin{array}{l}45 \cdot 0 \\
50 \\
-\end{array}$ & $\begin{array}{r}55 \cdot 0 \\
47 \cdot 8 \\
9 \cdot 4\end{array}$ \\
\hline $\begin{array}{l}\text { Flies homozygous } \\
\text { for an extracted } \\
\text { third chromosome }\end{array}$ & $\begin{array}{l}20^{\circ} \mathrm{C} . \\
25^{\circ} \mathrm{C} . \\
29^{\circ} \mathrm{C} .\end{array}$ & $\begin{array}{l}4 \cdot 6 \\
4 \cdot 2 \\
4 \cdot 3\end{array}$ & $\begin{array}{l}37 \cdot 3 \\
16 \cdot 2 \\
25 \cdot 4\end{array}$ & $\begin{array}{r}0 \cdot 4 \\
10 \cdot 4 \\
86 \cdot 8\end{array}$ & $\begin{array}{l}48 \cdot 8 \\
35 \cdot 4 \\
-\end{array}$ & $\begin{array}{l}50 \cdot 8 \\
54 \cdot 2 \\
13 \cdot 2\end{array}$ \\
\hline
\end{tabular}

As the line selected at $20^{\circ} \mathrm{C}$. had the highest scutellar bristle number it was used for a more complete analysis of whole chromosome effects. The results of scutellar bristle number assays of flies containing all possible combinations of extracted second and third chromosomes with Oregon second and third chromosomes (table 9) indicate that interactions between the second and third chromosomes contribute a substantial proportion to the total effect on scutellar bristle number. Dominance interactions further complicate the picture.

Flies homozygous for $\mathrm{X}$, second and third chromosomes extracted from the $20^{\circ} \mathrm{C}$. selected line were separately assayed at $20^{\circ} \mathrm{C}$., $25^{\circ} \mathrm{C}$. and $29^{\circ} \mathrm{C}$. (table 10). The $\mathrm{X}$ chromosome extracted from the $20^{\circ} \mathrm{C}$. selected line had no effect on scutellar bristle number at any of the three temperatures. Second chromosomes extracted from the line increased both the proportion of flies with extra bristles and the mean bristle number. The effect on mean was similar at each temperature, but the proportions of extra posterior bristles increased with increase in temperature. Extracted third chromosomes also increased mean bristle number at each temperature but the effect at $25^{\circ} \mathrm{C}$. was slight. In assays of both second and third chromosomes the proportion of extra posterior bristles was highest at $29^{\circ} \mathrm{C}$. 
It seems clear from these data that it is largely the positive interactions between second and third chromosomes which are affected by the culture temperaure and give rise to the differences in mean bristle number which are observed when the $20^{\circ} \mathrm{C}$. selected line is cultured at $25^{\circ} \mathrm{C}$. or at $29^{\circ} \mathrm{C}$. At $20^{\circ} \mathrm{C}$. the interaction component accounts for 1.8 bristles per fly or approximately 60 per cent. of the mean number of extra bristles, whereas at $25^{\circ} \mathrm{C}$. the proportion is 80 per cent. and at $29^{\circ} \mathrm{C}$., 28 per cent. (table 11).

Table 11

Estimates of the interaction component between $20^{\circ} \mathrm{C}$. selected line second and third chromosomes at different temperatures

$\begin{array}{lc} & \begin{array}{c}\text { Interaction } \\ \text { extra bristles per fly }\end{array} \\ 20^{\circ} \text { C. } & 1.8 \\ 25^{\circ} \text { C. } & 1.8 \\ 29^{\circ} \text { C. } & 0.2\end{array}$

\section{Discussion}

The differences in reactions to culture temperature observed in this material are in general similar to those described by Pennycuick and Fraser (1964) for non-scute flies. Mean scutellar bristle number increases with decrease in culture temperature from $29^{\circ} \mathrm{C}$. in a similar way to sternopleural bristle number (Beardmore, in Thoday, 1958). This relationship also holds for scute and non-scute populations selected for low scutellar bristle number (Druger, 1967; Gibson, unpublished) which have higher mean scutellar bristle numbers at $20^{\circ} \mathrm{C}$. than at $25^{\circ} \mathrm{G}$. In non-scute stocks selected for low scutellar bristle number at $25^{\circ} \mathrm{C}$. Gibson (1968) found a correlated change in the area of the scutellum which resulted from a decrease in cell number. Thus it is possible that the inverse correlation between temperature and scutellar bristle number may be associated with changes in the size of flies cultured at different temperatures. However, Fraser, Erway and Brenton (1968) compared the frequencies of flies with extra scutellar bristles in cultures enriched with dead yeast, and in cultures with 20 pairs of parents instead of four. The yeast-enriched cultures produced larger flies and the "crowded" cultures smaller flies, but both treatments gave rise to lower frequencies of flies with extra scutellar bristles than controls. Their data, therefore, do not appear to lend any support to the hypothesis that changes in fly size necessarily have any relation to the temperature effect.

Artificial selection can alter the responsiveness of scute populations to temperature (Druger, 1967; Kindred, 1965) and can reverse the relationship between scutellar bristle number and temperature. Natural selection affected the responsiveness of the present control lines to culture temperature but a more pronounced effect occurred in the line selected at $20^{\circ} \mathrm{C}$. The pattern of extra bristles produced when the Athens base population was first cultured at $20^{\circ} \mathrm{C}$. was replaced under selection for increased scutellar bristle number at $20^{\circ} \mathrm{C}$. by a different pattern, with a higher proportion of extra bristles at anterior sites.

The rate of response to selection for high scutellar bristle number showed an increase with increase in temperature but the differences between the 
means ultimately maintained at the three temperatures were greater than those suggested by the effect of temperature on the base stock. The heritability of scutellar bristle number in the Athens base stock may vary with temperature and this together with differences in phenotypic variability at the three temperatures may be sufficient to account for the different rates of response under directional selection. However, in view of the responses of the control lines it seems likely that natural selection favours higher scutellar bristle numbers at $20^{\circ} \mathrm{C}$. than at higher temperatures (Druger, 1967). Thus increased viability of flies with extra scutellar bristles at $20^{\circ} \mathrm{C}$. may lead to a more rapid utilisation of the genetic variability available.

Genetic analysis of the Athens base population provided some insight into possible modes of response to selection at $20^{\circ} \mathrm{C}$. for it revealed negative interactions between the second and third chromosomes at this temperature (Gibson, 1969). These data also provide an explanation for the results of Nassar (1965) and Nassar and Fraser (1965), who found that selection for extra scutellar bristles was enhanced when the genetic variance segregating in the base population was restricted to that from a single pair of chromosomes. Ambi-directional interchromosomal interactions would be expected to be a prominent feature of a highly stabilised character such as scutellar bristle number (Mather, 1943). Disruption of the stabilised genome would reveal cryptic variability which could lead to rapid responses to selection if the negative interactions had been relatively large. Accelerated responses to selection might frequently occur in this way in characters previously subjected to stabilising selection rather than from the formation of extreme genotypes by intrachromosomal recombination such as was demonstrated by Thoday and Boam (1961) in their sternopleural bristle selection lines (see Thoday et al., 1964). Fraser et al. (1965) describe a number of scutellar selection lines at $25^{\circ} \mathrm{C}$. in which rapid responses, similar to that in the present $20^{\circ} \mathrm{C}$. line, occurred for a few generations. A notable feature revealed by their genetic analysis of some of the selected lines was that whereas negative interactions between chromosomes were absent in the lines with the highest mean scutellar bristle number they were frequent components of lines which had shown a limited response to selection. Consonant results have recently been discussed by Whittle (1967). He analysed two populations selected for high scutellar bristle number which had been derived from two geographically isolated populations of $D$. melanogaster. Within each population interchromosomal interactions were largely positive whereas when chromosomes from the two populations were combined both negative and positive interactions occurred. Clearly negative interactions between chromosomes from different geographical areas were sheltered from the forces operating against such interactions in the separate selection lines yet their occurrence in the hybrids reveals vestiges of the stabilising systems, operating in the original populations.

Nevertheless, the removal of the negative interaction present in the Athens base population is not sufficient by itself fully to explain the response of the line selected at $20^{\circ} \mathrm{C}$. and whole chromosome analyses show that a major component of the response was due to the formation of positive interactions between second and the third chromosomes. The data also suggest that the magnitude of these interactions varied with the culture temperature and played a significant role in the rates of response to selection in the different environments. 
Of particular interest are the different effects of the culture temperature on the pattern of extra scutellar bristles. Extra posterior bristles are usually most frequent at $29^{\circ} \mathrm{C}$., extra anterior bristles predominate at $20^{\circ} \mathrm{C}$., and in the present material the $25^{\circ} \mathrm{C}$. lines are characterised by a high proportion of extra interstitial bristles. These relationships can be explained by the separate integrated action of different mechanisms, some of which were considered by Pennycuick and Fraser (1964). For example there might be genes affecting specific scutellar bristle number sites or the genes might affect all three sites. In either case the expression of the genes might vary with a temperature-controlled threshold or separate genes may function in different temperatures. Separate sub-samples of the same population selected for high scutellar bristle number in different temperatures might be expected to sort out those genes in the population which act in the different environments. The present data show that this process has not occurred, for all three selected lines can produce all types of extra scutellar bristles in the appropriate environment. Most of the extracted chromosomes assayed were effective to a similar extent in all three environments but the third chromosomes extracted from the $20^{\circ} \mathrm{C}$. line had less effect at $25^{\circ} \mathrm{C}$. than at the other two temperatures.

Reselection of the lines in new environments demonstrated that the $20^{\circ} \mathrm{C}$. line, which had ceased to respond at $20^{\circ} \mathrm{C}$., contained genetic variability which could be utilised by selection at $29^{\circ} \mathrm{C}$. But this further regime of directional selection at $29^{\circ} \mathrm{C}$. did not affect the mean scutellar bristle number of the line when it was cultured at $20^{\circ} \mathrm{C}$. These results suggest that some genes affecting scutellar bristle number operate over a short temperature range whereas others are less restricted (see also Gibson, 1969). The data provide no evidence for the hypothesis that there are separate genes affecting scutellar bristles for each of the three sites. But it is only possible to obtain such evidence if factors affecting one site, which do not have pleiotropic effects on the other two sites, can be located within a chromosome (Spickett, 1963). Whittle (1967) has shown that the polygene location techniques outlined by Thoday (1961) can profitably be used for locating scutellar bristle number genes so that such evidence might now be obtained.

\section{SUMmary}

1. Sub-samples of a wild type population of $D$. melanogaster were selected for extra scutellar bristles at $20^{\circ} \mathrm{C}$., $25^{\circ} \mathrm{C}$. and $29^{\circ} \mathrm{C}$. The effectiveness of selection was inversely related to culture temperature.

2. In both the $20^{\circ} \mathrm{C}$. and $25^{\circ} \mathrm{C}$. selected lines the proportion of extra bristles was highest at anterior sites whereas in the $29^{\circ} \mathrm{C}$. line a high proportion of extra posterior bristles was maintained.

3. Each of the selected lines had a higher mean scutellar bristle number at $20^{\circ} \mathrm{C}$. than at $29^{\circ} \mathrm{C}$. The proportion of extra posterior bristles increases and the proportion of extra anterior bristles decreases with a rise in culture temperature.

4. Reselection of the $20^{\circ} \mathrm{C}$. line at $29^{\circ} \mathrm{C}$. revealed genetic variance for scutellar bristle number which could not be utilised at $20^{\circ} \mathrm{C}$.

5. Chromosome assays of the $20^{\circ} \mathrm{C}$. selected line showed that the selection response was largely due to positive interactions between second and third chromosomes. The magnitude of the interaction varied with culture 
temperature. The data suggest that the same chromosomes affect scutellar bristle number and pattern differently at different temperatures.

\section{REFERENCES}

CHILD, G. 1935a. Phenogenetic studies on scute-1 of Drosophila melanogaster. I. The association between the bristles and the effects of genetic modifiers and temperature. Genetics, $20,109-126$.

CHILD, G. 1935b. Phenogenetic studies on scute-1 of Drosophila melanogaster. II. The temperature effective period. Genetics, 20, 127-155.

DRUGER, M. 1967. Selection and the effect of temperature on scutellar bristle number in Drosophila. Genetics, 56, 39-47.

FALCONER, D. s. 1960. Selection of mice for growth on high and low planes of nutrition. Genet. Res., 1, 91-113.

FINLAY, D. E. 1965. Selection for pattern of an artificially canalised character. Am. Nat., 99, 431-438.

FrASER, A. s. 1963. Variation of scutellar bristles in Drosophila. I. Genetic leakage. Genetics, 48, 497-514.

FRASER, A. s., ERWAY, L., AND BRENTON, w. 1968. Variation of scutellar bristles in DrosGphila. XIV. Effects of temperature and crowding. Aust. J. Biol. Sci., 21, 75-87.

FRASER, A. S., SNOWCROFT, W., NASSAR, R. F., ANGELES, H., AND BRAVO, G. 1965. Variation of scutellar bristles in Drosophila. IV. Effects of Selection. Aust. 7. Biol. Sci., 18, 619641.

GIBSON, J. B. 1968. Selection for the absence of scutellar bristles. Nature, Lond., 217, 188-190.

GIBSON, J. B. 1969. Effects of temperature on the development of scutellar bristles. Experientia, 25, 1198-1199.

KINDRED, B. 1965. Selection for temperature sensitivity in scute Drosophila. Genetics, 52, 723-728.

LATTER, B. D. H. 1964. Selection for a threshold character in Drosophila. I. An analysis of the phenotypic variance on the underlying scale. Genet. Res., 5, 198-210.

MAther, K. 1943. Polygenic inheritance and natural selection. Biol. Rev., 18, 32-64.

NASSAR, R. F. 1965. Variation of scutellar bristles in Drosophila. VIII. Selection and polygenes. Genetics, 52, 915-923.

NASSAR, R. F., AND fRASER, A. s. 1965. Selection and Polygenes. Nature, Lond., 206, 323-324.

PAYNE, F. 1918. An experiment to test the nature of the variation on which selection acts. Indiana Univ. Stud., 5, 1.45.

PENNYCUICK, P., AND FRASER, A. s. 1964. Variation of scutellar bristles in Drosophila. II. Effects of temperature. Aust. 7. Biol. Sci., 17, 764-770.

RENDEL, J. M. 1959. Canalisation of the scute phenotype of Drosophila. Evolution, 13, 425439.

RENDEL, J. M., AND SHELDON, B. L. 1960. Selection for canalisation of the scute phenotype of D. melanogaster. Aust. 7. Biol. Sci., 13, 36-47.

sismanidis, A. 1942. Selection for an almost invariable character in Drosophila. 7. Genet., 44, 204-215.

SPICKETT, s. G. 1963. Genetic and developmental studies of a quantitative character Nature, Lond., 199, 870-873.

THODAY, J. M. 1958. Homeostasis in a selection experiment. Heredity, 12, 401-415.

THODAY, J. м. 1961. Location of polygenes. Nature, Lond., 191, 368-370.

THODAY, J. м., AND BOAM, т. в. 1961. Regular responses to selection. I. Description o responses. Genet. Res., 2, 161-176.

THODAY, J. M., GIBSON, J. B., AND SPICKETT, s. G. 1964. Regular responses to selection. II. Recombination and accelerated response. Genet. Res., 5, 1-19.

WhItTle, J. R. s. 1967. Genetic Analysis of a Threshold Character. Ph.D. Dissertation, University of Cambridge. 